\title{
An Islamic banking perspective on consumers' perception in Pakistan
}

\begin{abstract}
Purpose - The aim of this research is to examine the perceptions of consumers on Islamic banking and finance in Pakistan. Islamic finance is an emerging phenomenon and its survival depends upon the availability, affordability and awareness. This thesis attempts to fill the gap in the literature by exploring the perceptions of consumers and bankers in an attempt to gain insights so that availability of products and awareness can be increased.
\end{abstract}

Design/methodology/approach - The study uses a regression model by employing perception as a dependent variable and awareness, knowledge and religious motivation as independent variables. The primary data is collected using 150 questionnaires distributed amongst finance students in several universities and employees of Islamic banks in Khyber Pakhtunkhwa (KPK) province of Pakistan.

Findings - The findings reveal that overall consumers' perception is positive about Islamic banking and finance in Pakistan. Statistical analysis shows that awareness, knowledge and religiosity level have positive influence on the perception of consumers about Islamic financing products and services in Pakistan. To improve the awareness and understanding, Islamic banks could make better marketing strategies and could increases their presence by mosque visits and conferences. A cooperation between the industry and scholars could help in more innovative products for the consumers.

Implications - There has been a limited amount of work carried out on the perceptions of consumers about Islamic banking in Pakistan. The present study represents start of a larger context for examining Islamic banking practices in Pakistan. The findings of the study can be used as a reference in future research projects in the areas of perceptions and awareness.

Originality/value - Little research has been conducted to study this problem from the perspectives of consumers and Islamic banking employees. Most research associated with Islamic banks fails to pay attention to these stakeholder groups in one study.

Keywords: Islamic Banking, Perception, Awareness, Knowledge, Religion, Pakistan. 


\section{Introduction}

Although Muslims have used Islamic financial products since the time of Prophet Muhammad (PBUH), the first study on Islamic finance did not appear until the mid-twentieth century (Mawdudi, 1961; Siddiqi, 1983). Since then, several Muslim and non-Muslim researchers have investigated the growth and phenomenon of Islamic banking (e.g. Iqbal and Mirakhor, 1999; El-Gamal, 2000; Warde, 2000; Wilson, 2006; Lewis and Algaud, 2001; Zaher and Hasaan, 2001; Ismail, 2002; Maurer, 2002; Siddiqi, 2002; Bley and Kuehn, 2004; Karbhari et al., 2004; Obaidullah, 2005; Iqbal and Molyneux, 2005; Ainley et al., 2007; Dusuki and Abdullah, 2007; Dusuki and Dar, 2007; Zainol et al., 2008; Kamla, 2009, Masood et al., 2009; Ali and Syed, 2010; Khan, 2010; Housby, 2011; Akbar et al., 2012; Filippo et al., 2013; Beloufi and Chachi; 2014; Kammer et al., 2015; and Riaz et al., 2016). There is a tendency in the Islamic finance literature to assume the theoretical superiority of Islamic banking, based on PLS, over the conventional interest-based banking system. Critics of conventional banking argue that the conventional system is based on profit maximisation and prompting banks to take high financial risks, resulting in social problems (Khan and Bhatti, 2008). Such concerns called an increase in demand for ethical alternatives to conventional banking system in West while making Islamic banking system one of the most debatable areas for academics (Wilson, 1997; Khan and Bhatti, 2008).

Recent years have witnessed a remarkable growth of Islamic banking and finance (Akbar et al., 2012). This kind of banking system bases its wisdom on Islamic economic system that emerged to free Muslims from colonisers from conventional system in practicing their religion over financial issues. Islamic Shariah law provides guidance in terms of belief, moral conduct, prohibitions, and practical rulings or laws to the Muslims under the Islam (Akbar et al., 2012; Beloufi and Chachi, 2014). The two basic sources of Islamic Shariah - the Holy Quran, and Hadith/Sunnah as the primary sources while secondary sources are Ijtihad and Qiyas $^{1}$ define Shariah law (Gait and Worthington, 2008). Sardar (2003) notes that 'Shariah'

\footnotetext{
${ }^{1}$ Ijtihad refers to further elaboration of the rules of the Quran and Sunnah to provide independent reasoning and analogy. This is developed by Islamic scholars to make rulings on situations where there is no clear or exact answer available. Imam Shafi was one of the first few individuals to bring a new kind of analogical reasoning in order to approach the Quran and Hadith. This new understanding was different compared to the consensus (Ijma) that scholars had established; a consensus which had been the main way of interpreting the holy texts up until Imam Shafi's work. This kind of legal reasoning became a core factor in the development Fiqh and has been widely referred to as "analogy" or Qiyas (Hallaq, 1997). Ijma refers to the agreement between religious scholars about a specific problem whose solution is not present in either the Quran and Sunna of the holy prophet (PBUH) (Gait and Worthington, 2008).
} 
which most Muslims translate it as Islamic law and to be divine, there is nothing divine about it. The only thing which precisely divine in Islam is the Quran. The Shariah is a "human construction; an attempt to understand the divine will in a particular context. Therefore, the bulk of the Shariah consists of Fiqh or jurisprudence, which is nothing more than legal opinion of classical jurists" (p. 28).

With strict philosophies of lending, Islamic banking gained popularity and success in several Muslim and non-Muslim countries. Renewed awareness and motivations in Islamic industry stemmed from its strong economic and social considerations, backed by its unique features (Akhtar, 2007). In recent years, Islamic Banking has seen an extensive growth in Pakistan ${ }^{2}$. The increasing number of branches and size of Islamic banks indicates the growth and success of Islamic banking industry. The motives behind this growth is due to the initiatives taken by State Bank of Pakistan (SBP) by creating a distinct Islamic banking division to make it the first choice and attractive for customers. This movement has generated new dimensions in this sector such as the financial need of small and medium enterprises, low cost housing, car financing and agriculture financing.

In terms of global outlook, Islamic banking is growing steadily, from one establishment in one country to about 600 institutions in more than 70 Muslim and non-Muslim countries (Beloufi and Chachi, 2014) $)^{3}$. The global market for Islamic banking is set to flourish significantly in the years ahead and has the potential for becoming a part of the international financial system (Nazeer, 2015) ${ }^{4}$. More importantly, during the global economic slowdown, Islamic finance has shown resilience whereas, conventional banks in the West experienced difficulties. Mosab et al. (2014) note that despite the financial crisis, the Islamic finance industry has been flourishing, and has enjoyed an astounding progress. The expansion of Islamic industry is arguably driven by the Gulf countries including Iran, Saudi Arabia, UAE

\footnotetext{
${ }^{2}$ According to Islamic banking bulletin March 2016 of state bank of Pakistan the total assets of Islamic banks are 1625 billion Rupees having $11.4 \%$ market share in the total banking industry of Pakistan

${ }^{3}$ The Shariah-compliant asset represents approximately 1 per cent of the global banking assets (Quilter-Pinner and Yan, 2013). With a projected yearly growth rate of between 10-15 per cent, Islamic Banking industry is likely to become an important international financial market in the future (UKIFS, 2013; Quilter-Pinner and Yan, 2013). Assets of IBI recorded Rs. 1,625 billion growth of 1 per cent during the first quarter of 2016 compared to Rs. 1,610 billion in the last quarter of 2015 REF. Deposits of Islamic banking reached to Rs. 1,336 billion at the end of March 2016. Market share of Islamic banking assets and deposits in total banking industry remained at 11.4 per cent and 12.9 per cent respectively at the end of March 2016 (IBB, 2016).

${ }^{4}$ Profitability after tax of Islamic banking industry recorded Rs. 2.9 billion at the end of March 2016. Return on equity (ROE) and Return on assets of Islamic banking industry showed 10.8 per cent and 0.7 per cent respectively in March 2016 (IBB, 2016).
} 
and Kuwait which represents nearly a third of the industry (Quilter-Pinner and Yan, 2013) 5 . However, other largest centres are concentrated in Malaysia and the UK with worth of US\$ 19 billion (Quilter-Pinner and Yan, 2013).

According to (Chachi, 2005), the first instances of Islamic banking and finance spurred in the late 1940's when Islamic scholars started to write books and articles. However, contemporary Islamic banking system started its operations in 1963 in Egypt. Through mid-1970's, a number of Islamic Banks started to operate in numerous Muslim countries such as Saudi Arabia, Sudan, Jordan, Egypt, UAE and Kuwait (Riaz et al., 2016). This wave of successful Islamic Banking hit outside the Middle-East, including Muslim and non-Muslim countries like Persian Gulf states, Indonesia, Pakistan and Malaysia (Warde, 2010; Rudnyckyj, 2013) ${ }^{6}$. 1970's and late 1980's was the predominant phase when largest number of Islamic Banks formed worldwide and developed the maturity phase (Karbhari et al., 2004). From 1980's onwards, Islamic Banks started spreading out to Europe, USA and Australia (Iqbal and Mirakhor 1999; Warde, 2010) ${ }^{7}$. Subsequently, major Shariah finance standard setting organisations were formed such as the Islamic Finance Services Board (IFSB), the Accounting and Auditing Organisation for Islamic Financial Institutions (AAOIFI) (Greuning and Iqbal 2007). Moreover, during that time many Muslim nations such as Pakistan, Malaysia, Iran, Indonesia, Saudi Arabia, Bahrain, Kuwait and Sudan signed an agreement to promote and practise common Islamic Banking and Finance system (Riaz, 2014). In December 2001, the State Bank of Pakistan established complete standards for the formation of full-fledged Islamic bank in the private sector. Al-Meezan Investment Bank was the first Islamic bank which received the license from State Bank of Pakistan in January 2002 and

\footnotetext{
${ }^{5}$ Countries such as Malaysia, Bahrain and Sudan have developed specific regulatory guidelines for Islamic banking industry (Greuning and Iqbal, 2007).

${ }^{6}$ Islamic banking was introduced by the formation of Bank Islam Malaysia Berhad in 1974. Since then it has expanded throughout the country forming other 80 branches; the bank was listed on the Kuala Lumpur Stock Exchange on January 1992. The Islamic Banking Act of 1983 allowed a dual banking system, which allowed both conventional and Islamic banking to operate side-by-side (Venardos, 2005). In Pakistan, the federal Shariah Court in July 1985 declared the procedures of the banks to be "un-Islamic" due to the mark-up technique (Khan 2009). In a meeting held on September 2001, under the chairmanship of President of Pakistan, it was decided to shift the whole economy to an interest free economy on a gradual basis without disturbing any financial operations. By the end of 2003 one bank (bankislami) was fully operational as an Islamic bank and three conventional banks were operating Islamic banking branches (Khan 2009). The State bank of Pakistan reported significant growth in the Islamic banking industry (Khan 2009).

7 The Islamic Development Bank in Saudi Arabia (1975), The Dubai Islamic Bank (1975), The Faisal Islamic Bank in Egypt (1976), The Faisal Islamic Bank of the Sudan (1977), The Jordan Islamic Bank (1978), The Islamic Development Bank in Saudi Arabia (1975), The Jordan Financial and Investment Bank (1978), The Islamic Investment Company Ltd in The United Arab Emirates (1978) and Kuwait Finance House (1979), Source: (Venardos, 2005, p. 64).
} 
began its operations as a first Islamic bank in Pakistan by the name of Meezan Islamic Bank ${ }^{8}$. Currently 6 full-fledge ${ }^{9}$ Islamic banks and 17 conventional banks are operative in Pakistan. There are 1168 branches of full-fledged banks, out of which 814 branches have Islamic window ${ }^{10}$.

While some argue that there is significant demand for Islamic financial services (Housby, 2013), there are still reasons to believe that the demand of for Islamic services may prove to be a mirage (Dusuki, 2007). This is because the assets of Islamic banks consist of financing based on genuine profit and loss sharing appears to be under 5 per cent (Lewis and Algoud, 2001; Dusuki 2007). For some, Islamic banking existence is still minimal and Islamic banking have not achieved the required growth levels (Dusuki and Dar, 2007; Rashid and Hassan, 2009). The first wave of Islamic products appeared to have benefited a large number of Muslims; misleading the rest of population into thinking that the remarkable growth in Islamic industry in the first few years in could be sustained indefinitely. In fact, the rate of growth has declined over the years, and different providers of finance are competing for the same customers (Housby, 2013). Long-term growth requires enticing new customers with no preceding business or interaction with Islamic finance. Prior studies have found lack of awareness and understanding amongst the consumers (Ahmad and Haron, 2002; Bley and Kuehn, 2004; Karbhari et al., 2004; Haque et al. 2009; Loo, 2010). The evidence suggests Islamic banking is failing in the challenge one of it's to be different from conventional banking; thus, it has not lived up to key goals (Kuran, 2004). Awareness of this failure within the industry would be a step on the road to changing current practices and awareness in order to align Islamic financial institutions' activities with Shariah principles of social justice. Little research has been conducted to study this problem from the perspectives of consumers and Islamic banking employees. Most research associated with Islamic banks fails to pay attention to these stakeholder groups in one study, hence, the motivation for this study.

The remainder of this study is organised as follows. Section 2 presents relevant literature which evaluates the Islamic banking paradigm and Islamic banking products and services. Section 3 provides a description of the research methodology and data. Section 4 reports results of the survey findings and provides a detailed explanation. Finally, Section 5

\footnotetext{
${ }^{8} \mathrm{http} / /$ ibp.org.pk/pdfs/files/SBP-Strategic\%20plan\%20for\%20Islamic\%20Banking\%20sector.pdf

${ }^{9}$ The banks are: Bank Islami Pakistan Limited; AlBaraka bank (Pakistan) limited; Burj Bank Limited; Dubai Islamic Bank Pakistan Limited; Meezan Bank Limited and MCB-Islamic Bank Limited

${ }^{10}$ www.sbp.org.pk/ibd/bulletin/2016/IBB-March-2016.pdf
} 
concludes the study by reporting the main findings, suggestions, limitations and avenues for future research.

\section{Literature Review}

\subsection{An Overview}

The Islamic economic system is based on the Shariah principles of equality and fairness (Kuran, 2004). In Islamic resource mobilisation system, contrary to the theory of capital via savings, money is not to be held in savings; it is 'mobilised' in the real economy by Shariahcompliant financing instruments such as Mudarabah, Musharakah and Murabahah. Theoretical approaches to Islamic finance argue that financial institutions should ensure that all practices are conducted in accordance with Shariah laws, especially that emphasising socio-economic justice and the prohibition on interest (Wilson, 1997; Zaher and Hassan, 2001; Beekun and Badawi, 2005; Kuran, 2004; Kamla, 2009). Hence, Islamic banks have developed several financing instruments that are free from Riba (interest) being based instead on profit and loss sharing. However, Siddiqi (2001), Haron and Hisham (2003) and Hassan and Musa (2003) note that Islamic banking is phenomena that is much more than the prohibition on interest. It is instead a system which aims to contribute to the fulfilment of socio-economic objectives and the establishment of social justice; it should also seek to establish a balance between earning and spending for the improvement of society as a whole (Haron, 1995; Al-Omar and Abdel-Haq, 1996).

Furthermore, Chapra (1992) argues that an Islamic economic system has four objectives: need fulfilment; the generation of income from sources which would be acceptable within Islam; the equitable distribution of income; plus, wealth, growth as and stability. Under an Islamic system, the economy would have to be restructured based on the objectives of Shariah. The system would promote a positive goal-oriented role for the government in raising moral consciousness and accelerating social as well as economic reforms with suitable incentives. Thus, Islamic finance is based on four main principles: (i) free consent, in which Islamic Shariah law requires the mutual consent of both parties before any contract is entered in to;

(ii) Islamic banking is characterised as an interest free system (Akbar et al., 2012). Prohibition of interest is one of the main principles that can lead to more stable system (Mohsin, 1986). According to Muslim scholars (e.g. Khan, 1986; Mannan, 1970; Lewis and 
Algoud, 2001) interest, being a predetermined cost of production, tends to prevent full employment of resources as it increases instability in the trade cycle, causing more intense fluctuations, by increasing the cost of capital (Keen, 1997); (iii) Prohibition of Gharar: an Arabic word interpreted as uncertainty, risk or speculation. According to El-Gamal (2000) Gharar is "the deal of things whose presence and features in types, species, amount of the thing, value, payment time etc. are uncertain" (p. 7); and (iv) profit and loss risk sharing: Islamic financial system encourages Muslims to invest their money in Halal (lawful) businesses effectively and become partners in the business instead of becoming lenders. So, in Islamic banking the depositor becomes investor and the manager works as an operational partner who invests their capital according to his expertise and effort for the return of the profit. At the end, they both equally share the risk according to their sharing of partnership.

\subsection{Islamic Banking Products and Services}

Ahmad (1994) suggests that Islamic banking within an Islamic economic system must be based on zero-based interest, equity participation, joint ventures and profit sharing. However, some studies (Siddiqi, 1985; Rosly and Bakar, 2003) regard profit-loss sharing (PLS) as the only strict principle of an Islamic banking system. Moreover, Islamic finance attempts to promote social justice through its products; it encourages ethics and endeavours to achieve an equal distribution of wealth and income (Kamla, 2009; Riaz et al., 2016). In Islamic banking, products such as Murabahah (mark-up financing), Ijarah (leasing), Musharakah (equity participation), Mudarabah (trustee finance contract) and Sukuk (Bonds) used as an alternative to interest bearing products (Zaher and Hassan, 2001; Usmani, 2002; Obaidullah, 2005; Mansuri, 2006; Housby, 2011).

\subsection{Accessibility and Bank Selection Criteria}

Lee and Ullah (2011) investigate motivational factors' leading to selection decisions in Islamic banks in Pakistan, using a sample of 357 questionnaires. Their study reveals that Pakistani Islamic banks' customers value Shariah compliance most highly in their banks. Abdul-Rehman and Masood (2012) used questionnaires to gather perceptions on the selection criteria used by Islamic banks. The results reveal that the Shariah principle is the most 
important factor considered by customers in choosing an Islamic bank, although service efficiency was also significant.

Awan and Azhar (2014) has explored the relationship between consumer behaviour towards bank selection criteria and customer satisfaction using a sample of 200 questionnaires Regression analysis was used to find the relationship between (religion, high profit \&low service charges, influence of friends \& family, service quality, responsive attitude of staff, mass media \& bank image) and customer satisfaction being the dependent variable. The findings reveal a positive and significant relationship between customer satisfaction and other variables. Subhani et al. (2012) have explored bank selection criteria by distributing 300 questionnaires in 9 Islamic Banks in Pakistan. The findings reveal that that high profit $\&$ low service charges were the most important factor in selection criteria factor followed by religious motives and quality of service preferred by the consumers. Khattak and Rahman (2010) and Okumus (2005) have also found consumers' awareness towards Islamic banking including current accounts and deposit accounts in Pakistan and Turkey However, products such as Murabahah and Ijarah, have reported the low awareness levels.

\subsection{Attitudes towards Islamic Banking}

A study by Ali and Syed (2010) investigates the impact of the perceptions and attitudes of professionals towards Islamic finance of the events of $9 / 11$. The authors find that although, the events in the US created false impressions and misconceptions about Muslims, it significantly contributed towards growth in, and awareness of, Islamic finance. Gait and Worthington (2008) conducted a research to review attitude, knowledge and perception towards Islamic banking from individual customer, business firm and financial institution. The findings showed that although consumers give importance to religion but there are still some other factors considered by customer for selection of a bank such as cost of finance, service quality and bank reputation. Zainol et al. (2008) investigated the perception of employees about products and services in Malaysia. The authors explored views of employees spread across both Islamic and conventional banks in Malaysia and found that employees in Islamic banks have greater knowledge than employees working in Islamic window of conventional banks. Haque et al. (2009) investigated consumers' perception about Islamic Banking in Malaysia. They analysed perception of customers as dependent variable and service quality, availability, confidence in bank and social and religious prospective) as 
independent variables by using Logit regression model. The result showed a significant positive association between dependent variable and independent variables. Furthermore, they explained that, availability of services along with social and religious perspective could make Islamic banking familiar and easy. Muniurrun et al. (2010) investigated basic elements of acceptance of Islamic banking in Malaysia in a descriptive method. The result showed that ethnic and religion factors have not so much influence on the selection of Islamic banking. They further suggested that as people's awareness level regarding Islamic banking is limited so the Islamic banks should enhance their promotion activities.

To enrich the literature on perceptions, Rustam et al. (2011) analysed corporate customers' perceptions towards Islamic banking in Pakistan. The result showed that Islamic banking products and services have a stout potential within corporate sector however, majority of the corporate consumers have limited knowledge about different Islamic banking products and services due to lack of marketing strategies of Islamic banks. The result also indicated that most of consumers considered religion as a key element, after that the most important factors were convenience, service delivery, reputation, size of bank and cost and benefit to company. Similarly, Khattak (2011) investigated perception of Pakistani corporate customers towards Islamic banking products and services in Pakistan. The author used correlation model ${ }^{11}$ for the data analysis. His results revealed that knowledge, cost and services were the key factors for corporate customers towards Islamic banking products and services.

Ahmed (2014) explored the perceptions of employees about products and services of Islamic banking in Oman. He found that while the banking employees have positive perceptions about products and services of Islamic banking nevertheless, they have very limited education and prior knowledge about Islamic banking. Another study by and Rehman and Shoaib (2014) investigated employee perception, knowledge and potential of Islamic banking in Pakistan. The results of 197 questionnaire surveys collected from the employees working in Islamic banks and Islamic-window reveal good level of understanding amongst those employees working in stand-alone Islamic banks those who working conventional banks with Islamic windows. An earlier study by Chhapra and Bhutto (2013) studied perception of post graduate students towards Islamic Finance in Pakistan using perceptions as dependent variable and religion, knowledge, service quality as independent variables. Their findings

${ }^{11}$ The model showed correlation relationship between dependent variable (corporate customer perception) and four independent variables (Awareness of Islamic banking, Marketing Strategy, Cost of the Services, Product). 
showed that all the independent variables (religion, knowledge and service quality) had a significant positive relation with dependent variable (perception of students). The study also revealed that religion and level of knowledge about Islamic products and services were equally important.

Adding further to existing literature on Islamic banking awareness and attitude, Khan and Asghar (2012) explored customer awareness and attitude towards Islamic banking in Pakistan. Their finding showed that people in Pakistan have positive attitude and sufficient awareness about Islamic banking because Pakistani people are now shifting from conventional banking to Islamic banking. Tara et al. (2014) investigated religious perception, awareness, reputation and networking as influencing variables in Islamic banking of Pakistan. The results revealed positive perceptions towards Islamic banking in Pakistan. The findings also indicated awareness to be most important influencing factor motivating Muslims towards Islamic banking in Pakistan.

\subsection{Islamic Banking Practices}

In exploring the performance of Islamic banking, Radiah (1993) investigated the performance and market implication of Islamic banking in Malaysia. The author reported that there were two kinds of Muslims customers in Malaysia; first kind of customers were religious and they only use Islamic banks due to strong religious belief as compare to any other element; and second kind of customers were moderate Muslims, who prefer services quality as primary factor over the religion over making a choice between Islamic and conventional banks. Adding further to existing literature on Islamic banking perceptions, Akbar et al. (2102) explored the issue of whether Islamic banking in the UK is fully aligned with the theoretical version of Islamic finance that emphasises the principles of profit and loss. On the basis of 35 responses the study reveals that most Islamic banks do not operate under the PLS system. These banks in practice follow the traditional interest-based model. The authors' overall conclusion is that Islamic banking in the UK cannot be seen as being aligned with the theoretical version of Islamic finance. Several other authors including Arif (2013) have noted that Islamic banking continue to grow in Pakistan and there are positive economic developments for the banks to grow and expand. The author indicated that Islamic banking keeps becoming innovative and new ideas for products would continue to expand the existing financial network. 
While previous researchers have examined the performance, choice criteria, motivational factors, efficiency, customer satisfaction, service quality, opportunities for development, views of employees and stakeholder perspectives, the perceptions and experience of everyday consumers, no study have explored the perceptions of consumers more specifically (postgraduate students studying on Islamic banking and finance courses) and only a handful amount of studies have sought the views of Islamic banking employees in Pakistan. The reason behind choosing students is that they have a good theoretical background of the Islamic banking and finance, whereas the knowledge and experience of banking employees of day-to-day banking operation would provide greater insights into the phenomena of Islamic banking and finance in Pakistan.

Hence, this study attempts to seal the gap by achieving these goals: (i) to explorer the perceptions of everyday consumers about Islamic financing products and services in Pakistan; (ii) to explore the strength of relationship between awareness and perceptions of consumers about Islamic financing products and services in Pakistan; (iii) to investigate the strength of relationship between knowledge and perception of consumers about Islamic financing products and services in Pakistan; and (v) to access the strength of relationship between religion and perception of Muslims about Islamic financing products and services in Pakistan. Based on these goals, this study investigates the following hypotheses:

H1: Awareness about Islamic financing products and services effect consumers' perception in Pakistan;

H2: Knowledge about Islamic financing products and services effect consumers' perception in Pakistan; and

H3: Religion affects consumers' perception about Islamic financing products and services in Pakistan.

\section{Methodology}

This study examines the perceptions of consumers about Islamic banking products and services in Pakistan by employing questionnaire surveys. Two versions of the document survey were distributed by hand between January and February 2016 to two stakeholder groups $^{12}$ including consumers and bankers. The primary data has been collected by

1210 pilot questionnaires were distributed to structure the questions in order to increase the response rate. 
distributing 150 questionnaires ${ }^{13}$ amongst postgraduate university students studying/or have completed Islamic finance qualification ${ }^{14}$ at different universities of Khyber Pakhtunkhwa (KPK) province of Pakistan ${ }^{15}$. These three universities are located in different cities ${ }^{16}$ of the KPK province: University of Peshawar; Abdul Wali Khan University (AWKU) Mardan and Hazara University Mansehra. While the banking employees survey was distributed in three cities of KPK province: Meezan Islamic Bank Peshawar (stand-alone); National Bank Pakistan in Mardan (Islamic-window) ${ }^{17}$; and The Bank of Khyber in Manshera (Islamicwindow $)^{18}$. The questionnaire survey is split into four key themes: perceptions; awareness; knowledge; and religious motivation in the perception about Islamic finance. The questions were adopted from previous study conducted by (Ling et al., 2012) and (Rehman and Shoaib, 2014). Section A of the questionnaire survey shows the demographic profile of the respondents including respondents' age, gender, religious level ${ }^{19}$, education and occupation; Sections B explores the issues relating to perceptions, impact of awareness, knowledge and religious motivation consumers about Islamic financing products and services in Pakistan ${ }^{20}$.

Tests including Cronbach's Alpha for reliability, Regression, ANOVA and Correlation were employed for an in-depth analysis of data to gather the perceptions of respondents. In this regard, Hussey and Hussey (1997) highlight that the use of different methods for studying the same phenomenon leads to greater reliability and validity. Table 1 provides detail about the demographic information of all 150 respondents including 75 University Students major in

\footnotetext{
${ }^{13} 85$ questionnaires were disturbed amongst students out of which 75 were completed, and 80 questionnaires were disturbed among the bank employees out of which 75 were completed.

${ }_{14}$ All of these respondents were either customers of Islamic banks or have been in the past.

${ }^{15}$ Pakistan is a federation of four provinces (Baluchistan, Khyber Pakhtunkhwa Punjab and Sindh); the Capital territory of Islamabad; and two territories (FATA, the Federally Administrative Tribal Areas, and GilgitBaltistan).

${ }^{16}$ These three cities (Peshawar,Mardan and Mansehra) are located apart from each other along with diversity on the bases of social, ethnical and economical grounds.

${ }^{17}$ We have distributed questionnaire in main branch of Meezan Bank Peshawar and National Bank of Pakistan Mardan.

${ }^{18}$ There are two branches of Bank of Khyber in Mansehra division - one in Abbottabad and other in Mansehra city. We have collected questionnaire from both branches.

${ }_{19}$ Religiosity level is an important factor for measuring demographic profiles of respondents because some of the previous studies like (Delener, 1990; Mokhlis, 2009; Radiah, 1993; Argue et al., 1999; Swimberghe et al., 2009) suggested that religiosity level also affect the individual choice towards Islamic banking. According to Radiah (1993) individuals having high level of religiosity are using only Islamic banks as compare to those having moderate level of religiosity in Malaysia. Religion is highly personal in nature and thus its influences on consumer behaviour depend on personse degree of religiosity (Swimberghe, et al., 2009; Mokhlis, 2009). According to Argue et al, (1999), time and age have positive relationship with the religiosity level of individuals. As the time and age of individual's passes the religiosity level also changes but in general non-linear manner.

${ }^{20}$ A copy of the questionnaire survey is shown in Appendix 1.
} 
finance and 75 bank employees. Cronbach alpha reliability test reported a score 0.87 implying an acceptable level of internal consistency in the survey results.

Inspection of Table 1 reveals a good diversity of respondents on various bases such as gender, age, education, occupation, and location, banks, university and religiosity level. In term of gender, 68 per cent were male students and 32 per cent were female. For the banker survey, 70 per cent were males and 30 per cent were male bankers. All of the participants from student survey were from the age group 18-30 years. The 59 per cent participants from bankers were from the 18-30 years, 40 per cent from the age group $31-42$ years and 1 per cent from the age group over 60 years, revealing that most of the participants where in the working class. While splitting the sample on the basis academic qualifications; 89 per cent had Master's qualification and 11 per cent held an MPhil degree from the students' survey. For the bankers' survey, 9 per cent had a matric qualification ${ }^{21}, 86$ per cent had an intermediate qualification (college) and 4 per cent had a Bachelor degree. In terms of strictness of religious views, 49 per cent of the students had very strict religious views, 46 per cent had moderate and 4 per cent at low sternness of views. In terms of bankers, 96 per cent of the respondents had strict religious views, and 4 per cent had moderate religious views. Students studying finance were from three different universities in different cities; 47 per cent of students were from the largest university of the province (i.e., University of Peshawar) and 27 per cent each from other two universities. Similarly, equal percentage of bank' employees 25 per cent were taken as sample from three different cities and banks.

${ }^{21}$ Matriculation is a term used to refer to the final year of high school and the qualification received on graduating from high school, which is equivalent to GCSE standards. 
Table 1: Demographic Characteristics of Respondents

\begin{tabular}{|c|c|c|c|c|}
\hline \multirow{2}{*}{ Variables } & \multirow{2}{*}{ Categories } & \multicolumn{3}{|c|}{ Respondent Numbers } \\
\cline { 2 - 5 } & Male & Students & Islamic Banks & Total \\
\hline \multirow{3}{*}{ Gender } & Female & 24 & 53 & 104 \\
& $18-30$ & 75 & 22 & 46 \\
\hline \multirow{4}{*}{ Age group } & $31-42$ & 0 & 34 & 119 \\
& $43-60$ & 0 & 0 & 30 \\
& $60+$ & 0 & 1 & 0 \\
\hline \multirow{4}{*}{ Academic } & Matriculation & 0 & 7 & 7 \\
qualification & Intermediate & 0 & 65 & 65 \\
& Bachelor & 0 & 3 & 3 \\
& Master & 67 & 0 & 67 \\
Religious & MPhil & 37 & 0 & 8 \\
strictness & Very strict & 35 & 3 & 109 \\
& Moderate & 3 & 0 & 38 \\
& Low strict & 25 & N/A & 3 \\
\hline \multirow{3}{*}{ University } & University of Peshawar & AWKU, Mardan & N/A & 25 \\
& Hazara University Mansehra & 25 & N/A & 25 \\
\hline \multirow{2}{*}{ City (Banking } & Meezan Bank Peshawar & N/A & 25 & 25 \\
Branch) & National Bank Pakistan Mardan & N/A & 25 & 25 \\
& Bank of Khyber Mansehra & N/A & 25 & 25 \\
\hline
\end{tabular}

Note: This table depicts demographic information about the respondent groups.

The study employs consumer perception as a dependent variable and awareness, knowledge and religious motivation as independent variables for exploring perceptions about Islamic financing products and services in Pakistan. The responses from 150 respondents are analysed using a regression analysis (Chhapra and Bhutto, 2013). Pearson Correlation Coefficient and Regression have been used to examine the association between dependent variable (perception) and independent variables (Knowledge, Awareness and Religious motivation). The regression analysis equation is:

$$
C P=\alpha+\beta 1(A)+\beta 2(K)+\beta 3(R)+\varepsilon
$$

* Where $C P=$ Consumer perception; $A=$ Awareness $;=$ Knowledge; $R=$ Religious motivation; $\varepsilon=$ Error Term

\section{Findings and Discussion}

\subsection{Reliability Analysis}

Table 2 shows Cronbach's Alpha to measure reliability of each theme. According to Hair et al., (1998) the standard value for reliability is 0.70 . The result shows that alpha value is 0.704 for perception, 0.779 for awareness, 0.862 for knowledge and 0.765 for religious motivation. 
All values of Cronbach's Alpha for each variable is greater than 0.70 indicating all variables of questionnaire to be reliable.

Table 2: Reliability Analysis

\begin{tabular}{|c|c|c|c|}
\hline Variables & Items & Cronbach's Alpha value & Results \\
\hline Perception & 6 & 0.704 & Reliable \\
\hline Awareness & 4 & 0.779 & Reliable \\
\hline Knowledge & 4 & 0.862 & Reliable \\
\hline Religious motivation & 4 & 0.765 & Reliable \\
\hline
\end{tabular}

Note: This table shows the reliability analysis of four variables.

\subsection{Regression Analysis}

Table 3 shows regression analysis of the study. In model (1), R represents coefficient of correlation which shows the strength of relationship between dependent and independent variable. The strength of relationship depends upon the closeness of $\mathrm{R}$ value to +1 or -1 . The value of $\mathrm{R}$ is closer to +1 shows a strong positive relationship whereas the value closer to -1 shows a strong negative relationship. Hence, in our test the value of $\mathrm{R}$ of 0.754 indicates moderate positive relationship among perception and other independent variables (awareness, knowledge and religious motivation). It shows that awareness, knowledge and religiosity level have positive influence on the perception of consumers about Islamic financing products and services in Pakistan. Moreover, in model (1) $\mathrm{R}^{2}$ represents Coefficient of Determination, which show the amount of variation in dependent variable because of independent variables. Here the value of $\mathrm{R}^{2}$ of 0.568 indicates that consumers perception level is $56.8 \%$ explained with the help of awareness, knowledge and religious motivation about Islamic financing products and services in Pakistan.

Table 3: Summary of Regression Analysis

\begin{tabular}{|c|c|c|c|c|}
\hline Model & $\mathbf{R}$ & $\mathbf{R}^{\mathbf{2}}$ & Adjusted $^{\mathbf{2}}$ & Std. Error of Estimate \\
\hline 1 & $0.754^{\mathrm{a}}$ & 0.568 & 0.559 & 0.31770 \\
\hline
\end{tabular}

a. Predictors: (Constant), Service Quality, Knowledge, Religious motivation

ANOVA, Analysis of variance has been used to determine the acceptance and precision of statistical model used in the study for finding the relationship between dependent and independent variables. In Table 4 , the value of $F$ is 63.971 , where $p$-value of 0.000 shows a 5 per cent significance level. This illustrates the accuracy of statistical calculation and the significance of relationship between of consumers' perception and three independent variables (awareness, knowledge and religious motivation). 
Table 4: Analysis of Variance ANOVA ${ }^{b}$

\begin{tabular}{|l|c|l|c|l|l|}
\hline Model & Sum of Squares & Df & Mean Square & $\boldsymbol{F}$ & Sig. \\
\hline Regression & 19.371 & 3 & 6.457 & 63.971 & $0.000^{\mathrm{a}}$ \\
Residual & 14.737 & 146 & 0.101 & & \\
Total & 34.108 & 149 & & & \\
\hline
\end{tabular}

a. Predictors: (Constant), Service Quality, Knowledge, Religious motivation.

b. Dependent Variable: Perception.

Table 5 shows the level of significance of individual variable in the form of t-statistics and pvalue. The first coefficient is the constant term or intercept term of the regression model. The beta $(\beta)$ value of constant is 1.972 shows that if awareness, knowledge and religious motivation are held zero then the perception of consumers remain at 1.972. The significance value of constant is $p=0.000$ specifying that the constant is significant.

Table 5: Regression Analysis showing the Coefficients Analysis

\begin{tabular}{|c|c|c|c|c|c|c|}
\hline & \multirow[t]{2}{*}{ Model } & \multicolumn{2}{|c|}{$\begin{array}{c}\text { Unstandardized } \\
\text { Coefficients }\end{array}$} & \multirow{2}{*}{$\begin{array}{c}\begin{array}{c}\text { Standardized } \\
\text { Coefficients }\end{array} \\
\text { Beta }\end{array}$} & \multirow[t]{2}{*}{$T$} & \multirow[t]{2}{*}{ Sig. } \\
\hline & & $\beta$ & Std. Error & & & \\
\hline \multirow[t]{4}{*}{ (1) } & Constant & 1.972 & 0.181 & & 10.921 & 0.000 \\
\hline & Awareness & 0.165 & 0.053 & 0.261 & 3.123 & 0.002 \\
\hline & Knowledge & 0.166 & 0.051 & 0.287 & 3.248 & 0.001 \\
\hline & Religion & 0.234 & 0.057 & 0.305 & 4.096 & 0.000 \\
\hline
\end{tabular}

a. Dependent Variable: Perception.

The beta $(\beta)$ value of Awareness (0.165) indicates that by changing the values of Awareness by 1 will cause $1.972+0.165$ changes in the consumers Perception. The p-value of awareness in our test is 0.002 (or $\mathrm{t}=3.123$ ). This shows a significant effect of awareness on the perception of consumers at 5 per cent level. This supports the first hypothesis of the study that awareness about Islamic financing products and services affect consumers' perception in Pakistan. The result is consistent with the findings of Masood et al. (2014) that customer perception about Islamic banking products and services is positively linked with the awareness level. The result also supports the prior findings of Khan and Asghar (2012) who reported that customers' attitude towards Islamic banking is linked with the awareness level. In addition, the finding of this study is consistent with the results of Abduh and Omarov (2013) that consumers' awareness about Islamic banking plays an important role in increasing their willingness towards Islamic banking.

The value of $(\beta)$ for Knowledge is 0.166 indicates that by changing the values of Knowledge by 1 will cause $1.972+0.166$ changes in the consumer's perception. The p-value of 0.001 
shows significant impact of knowledge on consumers' perceptions in Pakistan. This result supports the second hypothesis of the study that there is effect of knowledge on Islamic financing products and services in Pakistan. The finding is consistent with the outcome of Chhapra and Bhutto (2013) who found that level of knowledge about Islamic banking products and services significantly affects the perception of post-graduate students in Pakistan. The results are also consistent with the findings of Rehman and Shoaib (2014) who found that knowledge level of Islamic bank employees significantly influence their perception level in Pakistan. In addition, our findings are also in line with the results of Zainol et al. (2008) who noted that Islamic banking employees in Malaysia have greater level of knowledge which expressively influence their perception level.

Finally, religious motivation is the last slope of this model. The value of $\beta$ of 0.234 , indicates that by changing the value of $(\beta)$ by 1 causes $1.972+0.234$ changes in consumers' perception in Pakistan. Our p-value of 0.000 supports the third hypothesis of the study that religion has a significant effect on consumers' perception about Islamic products and services in Pakistan. The result is consistent with the findings of Chhapra and Bhutto (2013) that religion is one of the basic factor which significantly influences the perceptions of postgraduate students towards Islamic finance in Pakistan. The findings also support the result of Haque et al. (2009) and Radiah (1993) that customers' religiosity level has positive relationship with their perception level towards Islamic banking in Malaysia. Moreover, the results of our study are also consistent with the findings of Subhani (2012) and Awan \& Azhar (2014) that religious factor motivates consumer behaviour towards Islamic financing in Pakistan however, our results are dissimilar to the findings of Haron et al. (1994) who found that only 40 per cent consumers believe religion as a patronage factor towards Islamic banking in Malaysia.

The above findings conclude that awareness, knowledge and religious motivation have significant positive relationship with the perception of consumers about Islamic financing products and services in Pakistan. The result also shows overall perception of consumers is positive towards Islamic financing products and services in Pakistan as all variables (awareness, knowledge and religious motivation) have positive coefficient. Hence, the overall model we can frame is: 


\subsection{Correlation Analysis}

$$
M P=1.972+0.165(A)+0.166(K)+0.234(R)+\varepsilon
$$

Table 6 shows Pearson Correlation Analysis between variables which is significant at 0.01 level. Perception and Awareness have moderate positive correlation of 0.660; Perception and Knowledge have moderate positive correlation of 0.683 ; Perception and religious motivation have moderate positive correlation of 0.654; Awareness and Knowledge have moderate positive correlation of 0.743 ; Awareness and religious motivation have moderate positive correlation of 0.608 ; Knowledge and religious motivation have moderate positive correlation which is 0.661 . The results show that all variables perception, awareness, knowledge and religious motivation have a correlation value more than 0.60 indicating moderate positive correlation with each other (Branch, 1990). All values of correlation coefficient of independent variables are less than from 0.90 which shows there is no multi-collinearity problem in study (Hair et al., 1998).

Table 6: Pearson Correlation Analysis

\begin{tabular}{|l|c|c|c|c|}
\hline \multicolumn{1}{|c|}{ Variables } & Perception & Awareness & Knowledge & Religion \\
\hline Perception & 1 & $0.660^{* *}$ & $0.683^{* *}$ & $0.654^{* *}$ \\
\hline Awareness & 0.660 & 1 & $0.743^{* *}$ & $0.608^{* *}$ \\
\hline Knowledge & 0.683 & $0.743^{* *}$ & 1 & $0.661^{* *}$ \\
\hline Religion & 0.654 & $0.608^{* *}$ & $0.661^{* *}$ & 1 \\
\hline
\end{tabular}

** Correlation is significant at the 0.01 level (2-tailed).

\subsection{Summary of Statistical Analysis}

The value of $\mathrm{R}$ is 0.754 nearer to +1 specifies a moderate positive relationship among perception and other independent variables (Awareness, Knowledge and religious motivation). It indicates that awareness, knowledge and religiosity levels have positive influence on the perception of consumers about Islamic financing products and services in Pakistan. The $\mathrm{R}^{2}$ value of 56.8 per cent fitness of our regression model represent that consumers perception level is affected by awareness, knowledge and religious motivation about Islamic financing products and services in Pakistan. The beta $(\beta)$ value of constant is 1.972 with a significant $p$-value of 0.000 specifies that the constant is significant. This means that if awareness, knowledge and religious motivation are held zero then the perception of consumers would remain at 1.972 . The beta $(\beta)$ of Awareness 0.165 with a significant $\mathrm{p}$ value of 0.002 supports the first hypothesis of the study that awareness about Islamic 
financing products and services affect consumers' perception in Pakistan. The result is consistent with the findings of Masood et al. (2014); Khan and Asghar (2012); and Abduh and Omarov (2013) that consumers' awareness is a key factor in increasing the consumers' willingness towards Islamic banking. This shows a need to improve consumer perception towards Islamic banking services. As noted by Karbhari et al. (2004) that there is a need to raise general levels of awareness by ensuring consumers know that these products exist and to maintain confidence about the authenticity of the products. Islamic banks could advertise their products and services through conferences, newspaper, TV and mosque visits. The beta value $(\beta)$ of knowledge 0.166 and a p-value 0.001 shows the effect of knowledge on the perception of consumers about Islamic financing products and services in Pakistan supports the second hypothesis of the study. This finding is consistent with the results of Chhapra and Bhutto (2013); Rehman and Shoaib (2014); and Zainol et al. (2008). The result show that knowledge level of consumer is a key factor of perception about Islamic finance. Since Islamic finance contains Arabic terminology rather than Urdu or English which could be relatively difficult for consumers to understand or remember. These names of Islamic banking products and services could be off-putting to customers as previously reported by Bley and Kuehn (2004). To overcome this, the Islamic banks and institutions in Pakistan could work on improving the knowledge level of both consumer and bank employees. Knowledge and awareness are two binding factors towards achieving an overall positive perception towards Islamic banking.

Religious motivation is the last factor with a beta value $(\beta) 0.234$ and a p-value of 0.000 supports the third hypothesis of the study that religion has a significant effect on consumers' perception about Islamic products and services in Pakistan. This finding is consistent with the findings of Radiah (1993); Haque et al. (2009); Subhani (2012); Chhapra and Bhutto (2013); and Awan \& Azhar (2014). We believe that religious motivation may have since improved and consumers in Pakistan may have gained more religious conscious about financial activities. Finally, we conclude that all three factors (awareness, knowledge and religious motivation) have a strong impact on the overall perceptions of consumers about Islamic finance in Pakistan.

\section{Summary, Reflection and Way Forward}


The main purpose of this study was to explore the perceptions of consumers about the Islamic banking practices in Pakistan. 150 questionnaires were collected from two stakeholder groups: consumers and bankers. Our findings indicate that consumers reported dearth of understanding of Islamic financial terminology due to the lack of efforts from Islamic banks. To improve this, Islamic banks could design simpler products which are easier to understand, are highly competitive and more accessible for a wider public. Introducing courses related to Islamic finance to educate people at a school or college level could help people to understand the fundamentals of Islamic financial terminology. In addition, Islamic banks could make better marketing strategies in a comprehensive way to reach potential consumers for instance, this could be achieved by increasing banks' presence by mosque visits and conferences. In terms of improving Islamic banking practices, we suggest a cooperation between the industry and Islamic scholars. This integration could help in better Shariah-compliance, bringing out better ideas for innovative products and providing better advice on issues related to Islamic finance. Moreover, this integration could help consumers to overcome misconceptions about Islamic banking practices. In terms of improvements from the banking side, Chapra (2000) argues that Islamic banks must also develop further to show how Islamic values are reflected in legal, economic, social and political institutions. Islamic banks in countries such as Pakistan should also be able to devise instruments that can collect key economic variables to prepare a well-conceived programme for social and economic reforms. This collected data would be able to provide transparency, in particular, the data on the distribution of income and wealth and could help the Islamic financial institutions to make better products to fulfil the real socio-economic objective of Islamic finance. We believe that the Shariah framework of Islamic institutions should be re-thought and unless intellectuals and experts in modern economics sit with Islamic scholars in advisory boards, Islamic banking options would remain limited in scope and restricted in operation.

There has been a limited amount of work carried out on the perceptions of consumers about Islamic banking in Pakistan. The main contribution of our paper is that most of the previous studies have ignored multiple stakeholders and have only focused on one group at a time. Most significant are the views of consumers (Islamic finance students), which have not appeared in any recent study in Pakistan. A combination of voices gathered from Islamic banking employees and consumers should improve understanding of the actual perceptions towards the Islamic banking. While most of the previous studies reveal some inspiring and 
useful information, but most of these studies have been carried out to explore banking criteria and accessibility issues. Most of these studies have ignored the attitude, awareness, understanding and perceptions of Islamic banking phenomenon.

The above-mentioned findings would enable the notions of Islamic banking to be more accessible and disseminated that would eventually shape the future of the generations. Hence, the present study represents only the start of what we would hope becomes a larger context for examining Islamic banking practices in Pakistan. The findings of the study can be used as a reference in future research projects in the areas of perceptions and awareness of Islamic Banking in Pakistan. Our study could also contribute towards the present ${ }^{22}$ and future projects $^{23}$ on exploring the perceptions of consumers being conducted by the State Bank of Pakistan. However, there are few limitations and these are now acknowledged. We recognise that the sample size is relatively smaller and it is restricted only to KPK region of Pakistan. However, in seeking out potential respondents, extensive time and effort was devoted to ensuring that as wide a range of personal experiences and backgrounds were represented in the sample. Further work is clearly needed to examine for example, whether consumers favour Islamic financial institutions and banking over conventional ones? Do products and services of Islamic banks promote social justice? Whether Islamic scholars should play an important role in educating public on financial matters? Is there a need for revising current Islamic Banking practices in Pakistan to better meet the needs of consumers? Does Islamic Banking in Pakistan provide empowerment for women and young entrepreneurs? Can the industry ever truly thrive in the modern global economy and whether Islamic Banking should be viewed in the context of societal changes, such as globalization?

\footnotetext{
${ }^{22} \mathrm{http}: / /$ www.sbp.org.pk/publications/KAPStudy.pdf

${ }^{23} \mathrm{http}$ ://www.sbp.org.pk/departments/pdf/StrategicPlanPDF/Strategy\%20Paper-Final.pdf
} 


\section{References}

Abdul-Rehman, A. \& Masood, O. (2012), "Why do customers patronize Islamic banks? A case study of Pakistan", Oualitative Research in Einancial_Markets, Vol. 4, No. 2/3, pp. 130-141.

Abduh, M., \& Omarov, D. (2013) “Muslim's awareness and willingness to patronize Islamic banking in Kazakhstan.” Journal of Islamic Banking and Finance, Vol. 30, No. 3, pp. 16-24.

Ahmad, Z. (1994), "Islamic banking: state of the art". Islamic Economic Studies, Vol. 2, No. 1, pp. 1-34.

Ahmed, F. K. (2014), "Banker's Perceptions on Islamic Banking in Oman,” Asia Pacific Journal of Research. Vol, 1, No. XVI.

Ahmad, N. \& Haron, S. (2002), "Perceptions of Malaysian Corporate Customers towards Islamic Banking Products \& Services". International Journal of Islamic Financial Services, Vol. 3, No. 4, pp. 1-16.

Ainley, M., Mashayekhi, A., Hicks, R., Rahman, A. \& Ravalia, A. (2007), "Islamic finance in the UK: regulation and challenges". Working paper, Financial Services Authority, London.

Al-Omar, F. \& Abdel-Haq, M. (1996), "Islamic Banking: Theory, Practice and Challenges". Zed Books, London.

Ali, S. N. \& Syed, A. R. (2010), "Post-9/11 Perceptions of Islamic Finance”. International Research Journal of Finance and Economics, No. 39, pp. 29-37.

Akhtar, S. (2007), "Pakistan Islamic banking - past, present and future outlook". Keynote address by Dr Shamshad Akhtar, Governor of the State Bank of Pakistan, at Dawn Asia Finance Conference, Karachi,

Akbar, S., Syed Z. A. S \& Shahin, K. (2012), "An Investigation of User Perceptions of Islamic Banking Practices In, the United Kingdom". International Journal of Islamic and Middle Eastern Einance and Management Vol. 5, No. 4. pp. 353-370.

Argue, A., Johnson, D. R., \& White, L. K, (1999), “Age and religiosity: Evidence from a three-wave panel analysis," Journal for the Scientific Studv of Religion, Vol. 38, No. 3, pp. 423-435. 
Arif, M. (2013), "Islamic Banking” Asian Pacific Economic Literature, Vol 2, No. 2, pp. 4864.

Awan. A. G, Asghar. M, (2014), "Consumer Behavior towards Islamic banking in Pakistan". European Journal of Accounting Auditing and Finance Research. Vol.2, No. 9, pp. 42-65.

Beloufi, A. and Chachi, A. (2014), "Islamic Finance in the United Kingdom: Factors behind its Development and Growth”. Islamic Economic Studies, Vol. 22, No. 1, pp. 37-78.

Beekun, R. I. \& Badawi, J. A. (2005), "Balancing Ethical Responsibility among Multiple Organizational Stakeholders: The Islamic Perspective". Journal of Business Ethics, Vol. 60, pp. 131-145.

Bley, J. \& Kuehn, K. (2004), “Conventional Versus Islamic Finance Student Knowledge and Perception in the United Arab Emirates". International Journal of Islamic Financial Services, Vol. 5, No. 4, pp. pp. 17-30.

Branch, M. C. (1990), “Planning Universal Process (1st ed.),” New York: Praeger.

Boyd, W. L., Leonard, M. \& White, C. (1994), "Customer preferences for financial services: an analysis". International Journal of Bank Marketing, Vol. 12, No. 1, pp. 9-15.

Chachi, A. (2005), "Origin and Development of Commercial and Islamic Banking Operations". J.KAU: Islamic Econ., Vol. 18, No. 2, pp. 3-25.

Chapra, M. U. (1992), "Islam and the Economic Challenge" The Islamic Foundation, Leicester, U.K, pp. 426.

Chapra, M. U. (2000), "Is it necessary to have Islamic economics?" Journal of SocioEconomics. Vol. 29, No. 1, pp. 21-37.

Chhapra, I. U. \& Bhutto, S. (2013), “An Empirical Investigation on Perception of PostGraduate Students towards Islamic Finance in Islamic Republic Of Pakistan", Asian Journal of Research in Banking and Finance. Vol. 3, No. 12, pp. 68-80.

Delener, N. (1990), "The Effects of Religious Factors on Perceived Risk in Durable Goods Purchase Decisions". Journal of Consumer Marketing, Vol. 7, No. 3, pp. 27-38.

Dusuki, A. W. (2007), "The Ideal of Islamic Banking: A Surveys of Stakeholder's Perceptions". Review of Islamic Economics, Vol. 11, Special Issue, pp. 29-52.

Dusuki, W. A. \& Abdullah, I. N. (2006), "The ideal of Islamic banking: chasing a mirage”. Paper presented at INCEIF Islamic Banking and Finance Educational Colloquium, Kuala Lumpur, Malaysia.

Dusuki, A. W. \& Dar, H. (2007), "Stakeholders' perceptions of Corporate Social responsibility of Islamic Banks Evidence from Malaysian Economy". Advances in Islamic Economics and Finance, Vol. 1, pp. 249-277. 
El-Gamal, M. (2000), “A Basic Guide to Contemporary Islamic Banking and Finance”, Available at http://www.witness-pioneer.org/.

Filippo di Mauro, Caristi, P. Couderc, S., Di Maria, A., Grewal, L., Masciantonio, S., Ongena, S., and Zaher, S. (2013) Islamic Finance in Europe, Occasional Paper Series, No. 146, European Central Bank.

Gait, A. \&Worthington, A. (2008), “An Empirical Survey of Individual Consumer, Business Firm and Financial Institution Attitudes towards Islamic Methods of Finance", International Journal of Social Economics. Vol. 35 No. 11, pp. 783-808.

Ghani, U., Aziz, S. \& Niazi, M. A. K. (2015), "Do Customers Perceive Islamic Banking as Really Islamic? A Case of Pakistan". XIV International Business and Economy Conference Bangkok, Thailand.

Greuning, H. V. \& Iqbal, Z. (2007), "Risk Analysis for Islamic Banks". World Bank Publications.

Hair, J. F., Anderson, R. E., Tatham, R. L. \& Black, W. C, (1998), "Multivariate data analysis with reading," New Jersey: Prentice Hall.

Hallaq, W. B. (1997), “A History of Islamic Legal Theories: An Introduction to Sunni Usul al-fiqh”. Cambridge University Press.

Haque, A., Osman, J. \& Ismail, A. Z. (2009), "Factor Influences Selection of Islamic Banking: A Study on Malaysian Customer Preferences," American Journal of Applied Sciences. Vol. 6 No. 5, pp. 922-928.

Haron, S. (1995), "The Philosophy and Objective of Islamic Banking". Revisited, New Horizon, New York, NY.

Haron, S. \& Hisham, B. (2003), "Wealth mobilization by Islamic banks: the Malaysian case". Paper presented at International Seminar on Islamic Wealth Creation, University of Durham.

Haron. S, Ahmad. N. \& Planisek. S. L, (1994), "Bank Patronage Factors of Muslim and NonMuslim Customers,” International Journal of Bank Marketing, Vol. 12 No. 1, pp. 3240.

Hassan, N. M. N. \& Musa, M. (2003), "An evaluation of the Islamic banking development in Malaysia". Paper presented at International Islamic Banking Conference, Prato.

Housby, E. S. (2011), "Islamic financial services in the United Kingdom". Edinburgh, Edinburgh University Press.

Housby, E. S. (2013), "Islamic and Ethical Finance in the United Kingdom". Edinburgh University Press. 
Hussey, J. \& Hussey, R. (1997), "Business Research: A Practical Guide for Undergraduate and Postgraduate Students". Macmillan Business, London.

Iqbal, M. \& Molyneux, P. (2005), "Thirty Years of Islamic Banking: History, Performance and Prospects". Palgrave Macmillan, New York, NY.

Iqbal, Z. \& Mirakhor, A. (1999), "Issues and Challenges of Islamic Banking" with Abbas Mirakhor, Thunderbird International Business Review, Vol. 41, No. 4/5, pp. 381405.

Ismail, A. H. (2002), "The Deferred Contracts of Exchange: Al-Quran in Contrast with the Islamic Economist's Theory on Banking and Finance". Islamic Institute of Malaysia, Kuala Lumpur.

Kamla, R. (2009), "Critical Insights into Contemporary Islamic Accounting", Critical Perspectives on Accounting, Vol. 20, No. 8, pp. 921-932.

Kammer, A., Norat, M., Piñón, M., Prasad, A., Towe, C., Zeidane, Z., (2015), "Islamic Finance: Opportunities, Challenges and Policy Options". IMF Staff Discussion Note. International Monetary Fund. Available at: http://www.imf.org/external/pubs/ft/sdn/2015/sdn1505.pdf [Accessed 19-04-2015].

Karbhari, Y., Naser, K., \& Shahin, Z. (2004), "Problems and Challenges Facing the Islamic Banking System in the West: The Case of the UK". Thunderbird International Business Review, Vol. 46, No. 5, pp. 521-543.

Kaynak, E., Kucukemiroglu, O. \& Odabasi, Y. (1991), "Commercial bank selection in Turkey”. International Journal of Bank Marketing, Vol. 9, No. 4, pp. 30-40.

Keen, S. (1997), "From Prohibition to Depression: The Western Attitude to Usury". In Proceedings of International Conference 1: Accounting, Commerce and Finance: the Islamic Perspective, Sydney, Australia: University of Western Sydney, Macarthur.

Khan, A. G. (2009), "Growth of Islamic Banking in Pakistan". Institute of Business and Technology.

Khan, F. (2010), “How 'Islamic' is Islamic Banking?" Journal of Economic Behavior \& Organization, Vol. 76, No. 3, pp. 805-820.

Khan, M. S. (1986), "Islamic interest-free banking: a theoretical analysis", IMF Staff Papers, Vol. 33, No. 1, pp. 1-25.

Khan, H. N. \& Asghar, N. (2012), "Customer awareness and adoption of Islamic Banking in Pakistan," Interdisciplinary Journal of Contemporary Research in Business. Vol 3, No. 9, pp. 359-366.

Khan, M. M. \& Bhatti, M. I. (2008), "Islamic banking and finance: on its way to globalization”. Journal of Managerial Finance, Vol. 34, No. 10, pp. 708-25. 
Khattak, N. A, (2011), "Perception of Pakistani Corporate Customers toward Islamic Banking Products and Services (Case Related to Pakistan)," 2nd International Conference on Business and Economic Research (2nd ICBER 2011) Proceeding.

Khattak, N. A. and Rehman, K. U. (2010), "Customer satisfaction and awareness of Islamic banking system in Pakistan". African Journal of Business Management, Vol. 4, No. 5, pp. 662-672.

Kuran, T. (2004), "Islam and Mammon: The Economic Predicaments of Islamism". Princeton University Press, Princeton, NJ.

Lee, K. \& Ullah, S. (2011), "Customers' attitude toward Islamic banking in Pakistan". International Journal of Islamic and Middle Eastern Finance and Management, Vol. 4, No. 2, pp. 131-145.

Lewis, M. K. \& Algaoud, L. M. (2001), “Islamic Banking”. Cheltenham: Edward Elgar.

Ling, K. L., Ling, K. M., Pey, L. S. \& Hui, W. Z. (2012), “Awareness of Islamic Banking Products and Services among Non-Muslims in Malaysia," Thesis, University Tunku Abdul Rahman Malaysia.

Loo, M. (2010), "Attitudes and Perceptions towards Islamic Banking among Muslims and Non-Muslims in Malaysia: Implications for Marketing to Baby Boomers and XGeneration". International Journal of Arts and Sciences, Vol. 3, No. 13, pp. 453-485.

Mannan, M. A. (1986), "Islamic Economics: Theories and Practice" Originally Lahore: Islamic Publications, Sevenoaks, Kent: Hodder and Stoughton.

Masood, O., Aktan, B. \& Amin, Q. A. (2009), "Islamic banking: a study of customer satisfaction and preferences in non-Islamic countries". International Journal of Monetary Economics and Finance, Vol. 2, No. 3/4, pp. 261-85.

Masood, S., Rehman, S. \& Rehman. C. A. (2014), "Cognizing Customer Awareness and Perception of Islamic Banking Products in Pakistan," International Journal of Operations and Logistics Management, Vol, 3. No. 4, pp. 322-336.

Maurer, B. (2002), “Anthropological and accounting knowledge in Islamic banking and finance: rethinking critical accounts". Journal of Royal Anthropological Institute, Vol. 8, No. 4, pp. 645-667.

Mawdudi, S. A. A. (1961), “Sud (Interest)”, Lahore: Islamic Publications.

Metawa, S. A. \& Almossawi, M. (1998), "Banking behavior of Islamic bank customers: perspectives and implications". International Journal of Bank Marketing, Vol. 16, No. 7, pp. 299-313.

Mohsin, K. (1986), “Islamic Interest-Free Banking”, IMF Staff Papers, Vol. 33, No. 1, pp. 127. 
Mokhlis. S, (2009), "Relevancy and Measurement of Religiosity in Consumer Behavior Research,” International Business Research, Vol. 2, No. 3, pp. 75-84.

Mosab, I. T., \& Raj, S. D. (2014), "The Flow of Islamic Finance and Economic Growth: an Empirical Evidence of Middle East", Journal of Finance and Accounting. Vol. 2, No. 1, pp. 11-19.

Muniurrun, R. P. \& Naidoo, L. B. S. Y. P. (2010), "Service quality in the public service," International Journal of Management and Marketing Research, Vol. 3, No. 1, pp. 3750 .

Mansuri, M. T. (2006), "Islamic Law of Contracts and Business Transactions". Adam Publishers \& Distributors, New Delhi.

Nazeer, T., (2015), 'Tapping into Islamic finance' Public Finance. [Online] Available at: http://www.publicfinance.co.uk/feature/2015/05/tapping-islamic-finance [Accessed 11-06-2015].

Radiah, A. K, (1993), "Performance and Market Implication of Islamic Banking. A case study of Bank of Islam Malaysia Berhad". PhD. Thesis, Department of economics, University of Durham, U. K

Rudnyckyj D. (2013), "From Wall Street to Halal Street: Malaysia and the Globalization of Islamic Finance". The Journal of Asian Studies, Vol. 72, No. 4, pp. 831-848.

Obaidullah, M. (2005), "Islamic Financial Services". Islamic Economics Research Centre, King Abdul Aziz University, Jeddah.

Okumus, H. S. (2005), "Interest free banking in Turkey: a study of customer satisfaction and bank selection criteria". Journal of Economic Cooperation, Vol. 12, No. 4, pp. 51-86.

Quilter-Pinner, H. \& Yan, L. (2013), "Islamic finance: foreign policy opportunities" Foreign and Commonwealth Office. Available at: https://www.gov.uk/government/uploads/system/uploads/attachment_data/file/21125 4/Islamic_finance_note_final.pdf [Accessed 20-07-2015].

Rashid, M. \& Hassan M. K. (2009), “Customer Demographics Affecting Bank Selection Criteria, Preference, and Market Segmentation: Study on Domestic Islamic Banks in Bangladesh". International Journal of Business and Management, Vol. 4, No. 6, pp. 131-146.

Rehman, R. R. \& Shoaib, H. M. (2014), "Employee Perception, Knowledge and Potential of Islamic Banking in Pakistan”. Journal of Islamic Economics, Banking and Finance. Vol. 10, No .4, pp. 89-101.

Riaz, U. A. (2014), "Perceptions and Experiences of British-based Muslims on Islamic Banking and Finance in the UK". A Thesis Submitted for Degree of Doctor of Philosophy, University of Dundee, Dundee, UK 
Riaz, U. A., Burton, B. M. \& Monk, E. (2016), "Perceptions on Islamic banking in the UKPotentialities for empowerment, challenges and the role of scholars. Critical Perspectives on Accounting. Doi: http://dx.doi.org/10.1016/j.cpa.2016.11.002.

Rosly, S. A. \& Bakar, M. A. A. (2003), "Performance of Islamic and mainstream banks in Malaysia". International Journal of Social Economics, Vol. 30, No. 12, pp. 1249-65.

Rustam, S., Bibi, S., Zaman, K., Rustam, A. \& Haq, Z. (2011), "Perceptions of Corporate Customers towards Islamic Banking Products and Services in Pakistan," The Romanian Economic Journal, September, Vol. 14, No. 41, pp. 107-123.

Sardar, Z. (2003), "Islam, Postmodernism and Other Futures: A Ziauddin Sardar Reader" Eds. London: Pluto Press.

Siddiqi, M. N. (1983), "Issues in Islamic Banking, selected papers". Leicester, the U.K, the Islamic Foundation.

Siddiqi, M. N. (1985), "Partnership and Profit-Sharing in Islamic Law". The Islamic Foundation, Leicester, Leicestershire.

Siddiqi, S. H. (2002), "Islamic banking: true modes of financing". Journal of Islamic Banking \& Finance, Vol. 19, No. 1, pp. 11-24.

Islamic Banking Bulletin (2016), Islamic Banking Department, State Bank of Pakistan from www.sbp.org.pk/ibd/bulletin/2016/IBB-March-2016. Pdf

Subhani, M. I., Hasan, S. A., Rafiq, M. F., Nayaz, M. \& Osman, A. (2012), "Consumer criteria for the selection of an Islamic bank: evidence from Pakistan", International Research Journal of Finance and Economics. Vol. 94, pp.1-9.

Swimberghe, K., Sharma, D. \& Flurry, L. (2009), "An exploratory investigation of the consumer religious commitment and its influence on store loyalty and consumer complaint intentions". Journal of Consumer Marketing, Vol. 26, No. 5, pp. 340-347.

Tara, N., Irshad, M., Khan, M. R., Yamin, M. \& Rizwan, M. (2014), "Factors Influencing Adoption of Islamic Banking: A Study from Pakistan," Journal of Public Administration and Governance. Vol. 4, No. 3, pp. 352-367.

Usmani, M. T. (2002), “Islamic Finance,” Karachi: Maktaba Ma'ariful Qur’an.

Usmani, M. T. (2002), “An Introduction to Islamic Finance”. Kluwer Law International, The Hague.

Venardos, A. M. (2005), "Islamic Banking and Finance in Southeast Asia: Its Development and Future.” World Scientific Publishing Company, Singapore.

Warde, I. (2000), "Islamic Finance in the Global Economy". Edinburgh University Press, Edinburgh. 
Wilson, R. (2006), "Islam and Business". Thunderbird International Business Review, Vol. 48, No. 1, pp. 109-123.

Wilson, R. (1997), "Economics, Ethics and Religion: Jewish, Christian and Muslim Economic Thought". Macmillan in association with University of Durham.

Zainol, Z., Shaari, R. \& Ali, H. M. (2008), “A Comparative Analysis of Bankers’ Perceptions on Islamic Banking," International Journal of Business and Management Vol. 3, No.4, pp.157-168.

Zaher, T. S. \& Hassan, M. K. (2001), "A Comparative Literature Survey of Islamic Finance and Banking”. Financial Markets, Institutions \& Instruments, Vol. 10, No. 4, pp. 155-199. 
APPENDIX 1: Questionnaire Survey

\section{A. Background Information}

1. Pease place $(\sqrt{ })$ mark on your gender identity.
Male
$\square$ Female

2. Please select your age by picking tick $(\sqrt{ })$ the appropriate box.
$18-30$
$31-42$
$43-60$
$60+$

3. Please indicate your most recent educational qualification by picking tick $(\sqrt{ })$ the appropriate box.

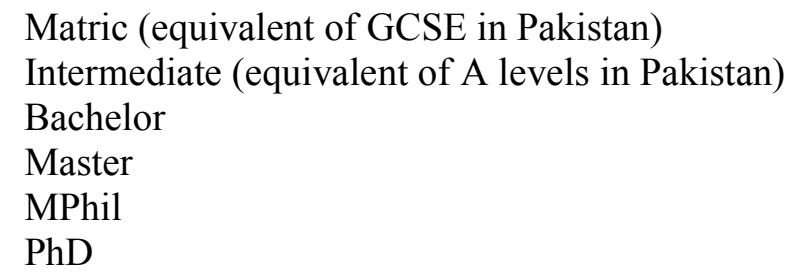

4. Please select your religious level by picking tick $(\sqrt{ })$ the appropriate box.
Very religious
Moderate
Very low 


\section{B. Perceptions and Awareness}

5. Please indicate the extent to which you agree or disagree with each of the following statements regarding Perceptions about Islamic financing products and services

\begin{tabular}{|l|l|l|l|l|l|}
\hline \multicolumn{1}{|c|}{ Statements } & (a) & & \\
& & \\
\hline $\begin{array}{l}\text { (a) Islamic financing products are based upon Shariah } \\
\text { principles }\end{array}$ & $\square$ & $\square$ & $\square$ & $\square$ & $\square$ \\
\hline $\begin{array}{l}\text { (b) Islamic banking products are more affordable than } \\
\text { conventional banks. }\end{array}$ & $\square$ & $\square$ & $\square$ & $\square$ & $\square$ \\
\hline $\begin{array}{l}\text { (c) Islamic banks are competitive than the conventional banks } \\
\text { in terms of the products and the quality of services }\end{array}$ & $\square$ & $\square$ & $\square$ & $\square$ & $\square$ \\
\hline $\begin{array}{l}\text { (d) Consumers prefer to deal with Islamic banks rather than } \\
\text { conventional banks. }\end{array}$ & $\square$ & $\square$ & $\square$ & $\square$ & $\square$ \\
\hline $\begin{array}{l}\text { (e) People have gained more knowledge of presence of the } \\
\text { Islamic banks in Pakistan }\end{array}$ & $\square$ & $\square$ & $\square$ & $\square$ & $\square$ \\
\hline $\begin{array}{l}\text { (f) The Government of Pakistan is helping Islamic banking } \\
\text { phenomena to flourish }\end{array}$ & $\square$ & $\square$ & $\square$ & $\square$ & $\square$ \\
\hline
\end{tabular}

6. Please indicate the extent to which you agree or disagree with each of the following statements regarding the awareness about Islamic financing products and services.

\begin{tabular}{|c|c|c|c|c|c|}
\hline Statements & 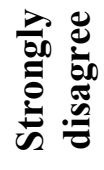 & 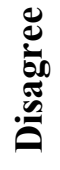 & $\begin{array}{l}\bar{\pi} \\
\bar{\Xi} \\
\bar{\Xi} \\
Z\end{array}$ & $\underbrace{8}_{0}$ & 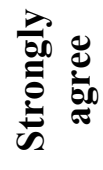 \\
\hline $\begin{array}{l}\text { (a) People have gained good understanding and awareness of } \\
\text { Islamic financing products in Pakistan }\end{array}$ & $\square$ & $\square$ & $\square$ & $\square$ & $\square$ \\
\hline $\begin{array}{l}\text { (b) There is a lack of awareness among people regarding the } \\
\text { availability of Islamic banking in Pakistan }\end{array}$ & $\square$ & $\square$ & $\square$ & $\square$ & $\square$ \\
\hline $\begin{array}{l}\text { (c) Islamic banks have good advertising strategies to inform } \\
\text { public about the financing opportunities in Pakistan }\end{array}$ & $\square$ & $\square$ & $\square$ & $\square$ & $\square$ \\
\hline $\begin{array}{l}\text { (d) Islamic institutions use a variety of methods to educate } \\
\text { people about their products and services }\end{array}$ & $\square$ & $\square$ & $\square$ & $\square$ & $\square$ \\
\hline
\end{tabular}


7. Please indicate the extent to which you agree or disagree with each of the following statements regarding knowledge about Islamic financing products and services.

\begin{tabular}{|c|c|c|c|c|c|}
\hline Statements & 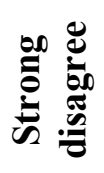 & 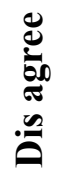 & Z & 莺 & 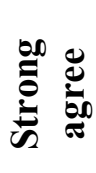 \\
\hline a. Islamic banking and finance in easier to understand & $\square$ & $\square$ & $\square$ & $\square$ & $\square$ \\
\hline $\begin{array}{l}\text { b. People have a good understanding of Mudarabah concept } \\
\text { (partnership based agreement) }\end{array}$ & $\square$ & $\square$ & $\square$ & $\square$ & $\square$ \\
\hline $\begin{array}{l}\text { c. People have a good understanding of Ijara (Islamic } \\
\text { leasing) }\end{array}$ & $\square$ & $\square$ & $\square$ & $\square$ & $\square$ \\
\hline $\begin{array}{l}\text { d. People are aware of Arabic terminology used in Islamic } \\
\text { banking and finance }\end{array}$ & $\square$ & $\square$ & $\square$ & $\square$ & $\square$ \\
\hline
\end{tabular}

8. Please indicate the extent to which you agree or disagree with each of the following statements regarding religious belief about Islamic financing products and services.

\begin{tabular}{|c|c|c|c|c|c|}
\hline Statements & 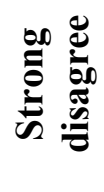 & 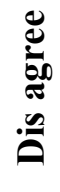 & Z & 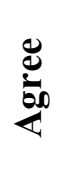 & 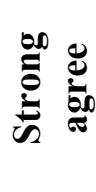 \\
\hline $\begin{array}{l}\text { a. Islamic banking in Pakistan provides a Shariah-compliant } \\
\text { alternative to conventional banking }\end{array}$ & $\square$ & $\square$ & $\square$ & $\square$ & $\square$ \\
\hline $\begin{array}{l}\text { b. People prefer to use Islamic banking products due to } \\
\text { Islamic prohibition of Riba (interest). }\end{array}$ & $\square$ & $\square$ & $\square$ & $\square$ & $\square$ \\
\hline $\begin{array}{l}\text { c. Islamic banks are transparent in its dealings and annual } \\
\text { reports. }\end{array}$ & $\square$ & $\square$ & $\square$ & $\square$ & $\square$ \\
\hline $\begin{array}{l}\text { d. People deal with Islamic banks due to religious } \\
\text { motivation }\end{array}$ & $\square$ & $\square$ & $\square$ & $\square$ & $\square$ \\
\hline
\end{tabular}

9. If you have any comments or concerns regarding Islamic banking in Pakistan, please use the space below to provide them. 